\title{
Properties of a Mutant of Bacillus subtilis 168 in which Spore Germination is Blocked at a Late Stage
}

\author{
By R. J. WARBURG* AND A. MOIR \\ Department of Genetics, University of Birmingham, P.O. Box 363, Birmingham B15 2TT
}

(Received 3 October 1980; revised 2 December 1980)

\begin{abstract}
A mutation, gerJ50, causing defective spore germination has been located between lys- 1 and trpC2 on the Bacillus subtilis map and is $92 \%$ cotransduced with $\operatorname{trpC2}$ by phage PBS1. Spores of strains containing gerJ50 will respond to germinants but the fall in absorbance is only $60 \%$ of that of the wild-type. During germination, mutant spores reach only an intermediate phase-grey stage, in contrast to those of the wild-type which become dark. The germination response, measured by the release of dipicolinic acid and the loss of resistance to heat, chloroform, octanol or toluene, is normal. The release of hexosamine-containing fragments from mutant spores is incomplete but has similar kinetics to that of wild-type spores. The mutant spores are more sensitive to heating at $90^{\circ} \mathrm{C}$ which may point to a structural abnormality, but there is no evidence of a spore coat deficiency from electron microscopy of thin sections or freeze fractures or from the chemical resistances of the spores. Thus, the germination of mutant spores is initiated normally, but blocked at a late stage.
\end{abstract}

\section{INTRODUCTION}

Germination of bacterial spores comprises the series of events that occur when resistant dormant spores develop into sensitive, actively metabolizing forms (Gould, 1969). In some species the spores must be activated, usually by heating, before they can respond to physical or, more commonly, chemical stimuli that will initiate germination. Germinants are thought to act by stimulating the spores such that they become irreversibly committed to losing their dormant properties (Scott et al., 1978). The process of germination itself is essentially degradative because the cortical peptidoglycan is depolymerized (Hamilton \& Stubbs, 1967) and dipicolinic acid (Powell \& Strange, 1953) is released from the core (Hashimoto \& Gerhardt, 1960) resulting in non-refractile spores which have lost about $30 \%$ of their dry weight and are fully sensitive to heat and chemicals. This process has been divided into two phases (Vary \& Halvorson, 1965), namely, the microlag, which is the time from the addition of germinant until loss in refractility, and microgermination, which entails its loss. In another subdivision Hashimoto et al. $(1969 \mathrm{~b})$ described a first stage as that which took place at high temperatures or high $\mathrm{CaCl}_{2}$ concentrations, and the second as that which was inhibited under these conditions.

The overall aim of our work is to understand the processes that occur immediately before and during spore germination and use is made of mutants whose spores do not respond to one or more of the germinants to which wild-type spores respond (Trowsdale \& Smith, 1975). In this paper we report the results of experiments on strains containing the germination mutation gerJ50, which differs from those previously described (Moir et al., 1979) in that spores of strains containing it are blocked at a later stage in germination. Its relationship to another germination mutation, gerE36 (Moir, 1981) which also gives rise to a block at a late stage in germination, is discussed. 


\section{METHODS}

Bacterial strains. All strains were derived from Bacillus subtilis 168 (Table 1). Strain 1604 (trpC2) and its derivative 4750 ( $g$ erJ50 $\operatorname{trpC2}$ ) are referred to in the text as the wild-type and mutant, respectively.

Media. Difco Penassay broth (PAB) was used as a liquid growth medium. Solid media were: Oxoid nutrient agar (NA; $1.5 \%$, w/v); soft nutrient agar (SNA; $1 \%$, w/v, NA, containing $\mathrm{NaCl}, 5 \mathrm{mg} \mathrm{ml}^{-1}$ ); potato glucose yeast extract agar (PGYEA; Dring \& Gould, 1971); Difco Tryptose blood agar base overlay containing $1 \%(\mathrm{w} / \mathrm{v})$ Difco Bacto agar and 2,3,5-triphenyltetrazolium chloride (TZM, $50 \mu \mathrm{g} \mathrm{ml} \mathrm{m}^{-1}$ ); and minimal salts (MS; Anagnostopoulos \& Spizizen, 1961) solidified with $1.5 \%$ (w/v) agar to give minimal agar (MA) in which amino acid supplements were at $20 \mu \mathrm{g} \mathrm{ml}^{-1}$ and glucose $\left(5 \mathrm{mg} \mathrm{ml}^{-1}\right)$ was used as the primary carbon source. MMDL plates contained MA, D-alanine $(10 \mathrm{mM})$, L-alanine $(10 \mathrm{mM})$, glucose $\left(5 \mathrm{mg} \mathrm{ml}{ }^{-1}\right)$, L-tryptophan $\left(20 \mu \mathrm{g} \mathrm{ml}^{-1}\right)$, $\mathrm{CaCl}_{2}(1.4 \mathrm{mM}), \mathrm{MnCl}_{2}(0.1 \mathrm{mM})$ and $\mathrm{MgCl}_{2}(2 \mathrm{mM})$. MMDL overlay contained $\mathrm{MS}$, TZM $\left(50 \mu \mathrm{g} \mathrm{ml}^{-1}\right)$, L-alanine $(15 \mathrm{mM})$, D-alanine $(40 \mathrm{mM})$ and agar $(1 \%, \mathrm{w} / \mathrm{v})$.

Preparation of spore suspensions. A $4 \mathrm{ml}$ portion of an exponential phase culture grown in PAB from a single colony on NA was spread on to a large $\left(600 \mathrm{~cm}^{2}\right)$ freshly poured area of wet PGYEA in a shallow dish and incubated for $24-28 \mathrm{~h}$ at $37^{\circ} \mathrm{C}$ or $80-90 \mathrm{~h}$ at $26^{\circ} \mathrm{C}$ to yield at least $80 \%$ phase-bright spores. The harvesting and washing procedure was described by Lafferty \& Moir (1977) except that at the fourth washing the spore suspension was treated with lysozyme $\left(200 \mu \mathrm{g} \mathrm{m}^{-1}\right)$ in saline $(0.085 \%, \mathrm{w} / \mathrm{v})$ for $30 \mathrm{~min}$ at $20^{\circ} \mathrm{C}$. Spore suspensions in distilled water were stored at $4{ }^{\circ} \mathrm{C}$ at a density of $5 \times 10^{8}$ spores $\mathrm{ml}^{-1}$.

Germination studies. The germination of spore suspensions was followed by measuring the fall in absorbance at $580 \mathrm{~nm}$ at $37^{\circ} \mathrm{C}$ using a Vitatron U.P.M. spectrophotometer. Readings were taken at $5 \mathrm{~min}$ intervals over a $60 \mathrm{~min}$ period after the addition of heat-activated spores $\left(30 \mathrm{~min}\right.$ at $\left.70^{\circ} \mathrm{C}\right)$ to prewarmed germinant, and were expressed as a percentage of the initial $A_{580}$ value (about $0 \cdot 3$ ). Germinants used were L-alanine (up to $10 \mathrm{mM}$ ), D-alanine (up to $10 \mathrm{mM})$, asparagine $(10 \mathrm{mM}), \mathrm{D}$-glucose $(10 \mathrm{~mm})$, D-fructose $(10 \mathrm{mM}), \mathrm{KCl}(10 \mathrm{mM})$ and PAB; all except PAB were used in $10 \mathrm{~mm}$-Tris $/ \mathrm{HCl}$ buffer, adjusted to $\mathrm{pH} 8.4$ at $20^{\circ} \mathrm{C}$.

The germination phenotype of stab inocula of the mutants was determined by the tetrazolium overlay method of Moir et al. (1979). In addition, spore-containing colonies were prepared on MMDL plates by incubation at $37^{\circ} \mathrm{C}$ for $3 \mathrm{~d}$; these were then exposed to chloroform vapour at $20^{\circ} \mathrm{C}$ for $3 \mathrm{~h}$, overlaid with MMDL and incubated at $37^{\circ} \mathrm{C}$ for $6 \mathrm{~h}$. In both these tests the wild-type colonies reduced the dye to give a red colour.

Release of dipicolinic acid (DPA) was determined at 5 min intervals in $3 \mathrm{ml}$ samples of germinating spore suspensions. The samples were passed through Millipore filters $(0.45 \mu \mathrm{m}$ pore size $)$ and the DPA content of the filtrates was determined by the method of Scott \& Ellar (1978).

\section{Table 1. Strains of Bacillus subtilis 168}

\begin{tabular}{|c|c|c|}
\hline $\begin{array}{c}\text { Strain } \\
\text { designation }\end{array}$ & Genotype* & Origin $\dagger$ \\
\hline 1604 & $\operatorname{trp} C 2$ & Moir et al. (1979) \\
\hline 4750 & $\operatorname{trp} C 2$ gerJ 50 & Ultraviolet irradiation of 1604 \\
\hline MB21 & metC3 leuA8 tal-1 & P. Piggot \\
\hline BD92 & hisAl cysB3 trpC2 & C. Anagnostopoulos \\
\hline BD 111 & thr $-5 \operatorname{trp} C 2$ cys $B 3$ & D. Dubnau \\
\hline BD 112 & cysA 14 & D. Dubnau \\
\hline GSY334 & leuA8 & C. Anagnostopoulos \\
\hline 1506 & lys -1 & Spontaneous Trp ${ }^{+}$revertant of GSY254 (C. Anagnostopoulos) \\
\hline 4756 & gerJ50 & Lys $^{+}$transductant from PBS 1 cross $1506 \times 4750$ \\
\hline SB455 & $m t r$ & E. Nester \\
\hline IA 132 & $\operatorname{trp} C 2$ aroC 7 & $\begin{array}{l}\text { Bacillus Genetics Stock Center. SB121 of E. Nester. Contains a } \\
\text { TZM-white marker }\end{array}$ \\
\hline 9098 & $\operatorname{trpC2}$ aroc7 & Lys $^{+}$transductant of PBS 1 cross $1506 \times$ IA 132 \\
\hline SB 137 & hisB2 aroB2 & Nester et al. (1963). Contains a TZM-white marker \\
\hline 4783 & his $B 2$ aroB2 & Trp $^{+}$transductant from PBS1 cross $1604 \times \mathrm{SB} 137$ \\
\hline SL646 & leuA8 spoIVA67 tal-1 & P. Piggot \\
\hline 1408 & $\operatorname{trpC2} 2$ & Trowsdale \& Smith (1975). Contains a TZM-white marker \\
\hline 1488 & gerC88 trpC2 wrd & NTG mutagenesis of 1408 \\
\hline 1558 & gerC58 trpC2 wrd & NTG mutagenesis of 1408 \\
\hline 9020 & $\operatorname{trpC2}$ gerC88 & Aro $^{+}$transductant from SPP 1 cross $4783 \times 1488$ \\
\hline 4600 & gerE36 trpC2 his & Moir et al. (1979) \\
\hline
\end{tabular}

* The wrd mutation confers a temperature-sensitive growth phenotype (Trowsdale \& Smith, 1975); the mtr mutation confers resistance to tryptophan analogues (Hoch et al., 1971).

+ NTG, $N$-methyl- $N^{\prime}$-nitro- $N$-nitrosoguanidine; TZM, 2,3,5-triphenyltetrazolium chloride. 
Spore resistance was measured for both germinating and dormant spore suspensions by adding $0 \cdot 1 \mathrm{ml}$ samples (containing about $5 \times 10^{7}$ spores) to $10 \mathrm{ml} \mathrm{MS}$ and incubating $2 \mathrm{ml}$ of these dilutions either at $70^{\circ} \mathrm{C}$ for $30 \mathrm{~min}$ to measure heat resistance or with $0.25 \mathrm{ml}$ chloroform, toluene or octanol (after 1 min vortexing) for $30 \mathrm{~min}$ at $20^{\circ} \mathrm{C}$. Viable counts of serial dilutions of treated and untreated suspensions were determined in duplicate in $3 \mathrm{ml}$ SNA layers on NA plates incubated at $37^{\circ} \mathrm{C}$ for $15 \mathrm{~h}$.

Germinating or dormant suspensions were observed with a Zeiss GFL phase contrast microscope, using a green filter, at $800 \times$ magnification. Photographs were taken on Kodak-50 professional film, using a Leitz Wetzlar Ortholux II phase contrast microscope without filters.

To follow the release of hexosamine-containing fragments during germination, a concentrated suspension of spores $\left(A_{580}\right.$ about 400$)$ was heat-activated $\left(30 \mathrm{~min}\right.$ at $\left.70^{\circ} \mathrm{C}\right)$ and diluted 10 -fold into a mixture of L-alanine $(10 \mathrm{mM}), O$-carbamyl-D-serine $\left(5 \mathrm{mg} \mathrm{ml}^{-1}\right)$ as an alanine racemase inhibitor, and Tris/ $\mathrm{HCl}$ buffer $(10 \mathrm{mM}$, $\mathrm{pH} 8.4$ at $20^{\circ} \mathrm{C}$ ) at $37^{\circ} \mathrm{C}$. Samples of $1 \mathrm{ml}$ were taken at $5 \mathrm{~min}$ intervals and centrifuged for $2 \mathrm{~min}$ at $12000 \mathrm{~g}$; hexosamine in both the supernatants and pellets was measured by the method of Warth (1971), after hydrolysis of the samples in $6 \mathrm{M}-\mathrm{HCl}$ for $2 \mathrm{~h}$ at $100^{\circ} \mathrm{C}$ in vacuo, and compared with a glucosamine standard. The progress of germination was also monitored in parallel by measuring the $A_{580}$ of a 1 in 30 dilution of the spore suspensions.

Measurement of spore heat resistance $\left(D_{90}\right)$. A $0.1 \mathrm{ml}$ portion of a spore suspension was added to $10 \mathrm{ml}$ MS at $90^{\circ} \mathrm{C} ; 0.1 \mathrm{ml}$ samples were taken at intervals, diluted in MS, plated in $3 \mathrm{ml} \mathrm{SNA}$ on NA plates and incubated at $37^{\circ} \mathrm{C}$ for $15 \mathrm{~h}$. The $\mathrm{D}_{90}$ value was determined as the time taken for the number of colony-forming units in samples to fall to $10 \%$ of the original value.

Mutant isolation procedure. A $5 \mathrm{ml}$ portion of a mid-exponential phase culture of strain 1604 (wild-type) in PAB was centrifuged, resuspended in $1 \mathrm{ml} 100 \mathrm{mM}_{-} \mathrm{MgSO}_{4}$ and irradiated with ultraviolet light to give $0.1 \%$ survival. A spore suspension was prepared in water and $0.8 \mathrm{ml}$ of this suspension $\left(A_{580} 3.0\right)$ was added to $6 \mathrm{ml}$ Tris/ $\mathrm{HCl}(0.1 \mathrm{M}, \mathrm{pH} 7.4)$ containing L-alanine $(0.1 \mathrm{M})$, D-alanine $(0.1 \mathrm{M})$ and $O$-carbamyl-D-serine $(0.1 \mathrm{M})$ and incubated at $37^{\circ} \mathrm{C}$ for $2 \mathrm{~h}$. After centrifugation and resuspension in $5 \mathrm{ml}$ water, $2 \mathrm{ml}$ of the resulting suspension was layered on to $8 \mathrm{ml}$ Endografin, $\rho=1.255$ [Schering Chemicals; prepared as a $68 \%(\mathrm{v} / \mathrm{v})$ dilution in distilled water of a $70 \%(\mathrm{w} / \mathrm{v})$ solution] and centrifuged for $30 \mathrm{~min}$ at $4{ }^{\circ} \mathrm{C}$ at $22000 \mathrm{~g}$. The upper layer, containing mainly germinated spores, was centrifuged on fresh Endografin; the upper layer was again removed, and suitable dilutions were plated on PGYEA and incubated at $37^{\circ} \mathrm{C}$. Colonies were then stab-inoculated on to fresh PGYEA in glass Petri dishes, incubated at $37^{\circ} \mathrm{C}$ to allow sporulation and exposed to chloroform for $3 \mathrm{~h}$; inocula were stabbed to further PGYEA and MMDL glass plates to test TZM reactions.

Transduction. Phage PBS1 was used as described by Moir et al. (1979). Phage SPP1 was used as described by Ferrari et al. (1978) except that vegetative cells were used, rather than spores, to prepare lysates.

Transformation. DNA was prepared from vegetative cells by the method of Marmur (1961) and transformation was performed by a modification of the method of Anagnostopoulos \& Spizizen (1961). Cells were grown overnight on MA containing glucose, casein hydrolysate $(0.02 \%)$ and any required amino acids $(50 \mu \mathrm{g}$ $\left.\mathrm{ml}^{-1}\right) . \mathrm{MgSO}_{4}(5 \mathrm{~mm})$ and trace elements $\left(\mathrm{FeCl}_{3}, \mathrm{CaCl}_{2}, \mathrm{ZnCl}_{2}\right.$ and $\mathrm{MnCl}_{2}$, each $\left.10 \mu \mathrm{M}\right)$ were added to the transformation media.

Electron microscopy. Methods used were essentially similar to those described by Luft (1956) and Sousa et al. (1974). Washed spore pellets produced at $26^{\circ} \mathrm{C}$ were suspended in either $2 \%(\mathrm{w} / \mathrm{v}) \mathrm{KMnO}_{4}$ for $90 \mathrm{~min}$ at $37^{\circ} \mathrm{C}$, or in phosphate buffer $(\mathrm{pH} 7.3)$ containing $3 \%(\mathrm{w} / \mathrm{v})$ glutaraldehyde for $90 \mathrm{~min}$ at $4{ }^{\circ} \mathrm{C}$ followed by treatment with $1 \%(\mathrm{w} / \mathrm{v})$ osmium tetroxide for $2 \mathrm{~h}$ at $20^{\circ} \mathrm{C}$. The resulting pellets were then washed, resuspended in $1 \%$ agar, dehydrated, embedded in the resin of Spurr (1969), and gold to silver grey sections were cut. Glutaraldehydetreated sections were also stained with uranyl acetate and lead citrate. Other spore pellets were suspended in $30 \%$ $(\mathrm{v} / \mathrm{v})$ glycerol overnight, and then a fracture was made at $-110^{\circ} \mathrm{C}$ and coated immediately with platinum and carbon.

\section{RESULTS \\ Isolation of the mutant}

The selection procedure was designed to enrich for spores that were able to germinate in the presence of D-alanine (a competitive inhibitor of L-alanine-stimulated germination; Wolf \& Mahmoud, 1957) so that comparison with mutants thought to be blocked in the L-alanine response (Moir et al., 1979) could be made. Of 240 colonies tested, 5 were TZM-white on PGYEA plates and 10 on MMDL plates; none were white on both media. For each of these 15 potential mutants, the fall in absorbance of spore suspensions in L-alanine was inhibited by D-alanine to the same extent as for the wild-type.

Spores from one colony (strain 4750, mutation ger-50), which was TZM-white on MMDL plates, reached only a phase-grey stage during germination in L-alanine. On closer study of 
the PGYEA TZM plate test we found that when the plates were incubated for only $4 \mathrm{~h}$ at $37^{\circ} \mathrm{C}$ the mutant clones were pale red, assuming the normal dark red colour after a further $2 \mathrm{~h}$ at $37^{\circ} \mathrm{C}$, although spores in these clones were phase-grey while those of the wild-type were phase-dark.

\section{Map location of ger-50}

A phage PBS1 lysate of the mutant was used to transduce a series of auxotrophs to prototrophy. The germination phenotype of the recombinants was determined using the PGYEA TZM test. No linkage to metC 3 , leuA8, hisA1, cysB3, thr-5 or cys $A 14$ was detected but cotransduction with $\operatorname{trp} C 2(92 \%)$ and $l y s-1$ (79\%) was obtained (Table 2, crosses 1 and 2 ) and the results of a three-point cross were consistent with the order lys-1-ger-50-trpC2 (cross 1).

Finer mapping was then carried out using phage SPP 1 transduction and transformation. Crosses 3 and 6 demonstrate that ger-50 is on the trpC2-distal side of both $m$ tr and aroC7. Crosses 4 and 5 establish that ger-50 is approximately $13 \%$ and spoIVA67 approximately $60 \%$ linked to aroB2 in SPP1 transduction and thus that the two mutations are well separated. The relative orders of aroC7, $m t r, s p o I V A 67, \operatorname{aroB2}, \operatorname{trp} C 2$ and hisB2 have been determined previously (Nester et al., 1963; Piggot, 1973) and so the following order can be deduced: lys-1-ger-50-aroC7-mtr-spoIVA67-aroB2-trpC2-hisB2.

The fall in absorbance of spore suspensions of at least three TZM-white and at least three TZM-red recombinant colonies from each of the crosses was tested and in each case found to be identical to the parental strain with the similar TZM reaction. This confirmed the association between TZM phenotype and possession of the germination defect. Since the map location of the ger-50 mutation was different from those of other germination mutants (Moir et al., 1979) it was assigned the location letter $\mathrm{J}$ thus becoming gerJ50.

Two other mutations ( $g$ erC58 and gerC88) are located near the lys-1 and trpC2 markers (Trowsdale \& Smith, 1975). These differ from gerJ50 in that they are associated with another marker wrd (from which they could be separated in PBS1 crosses; Moir et al., 1979), their germination in L-alanine is temperature-sensitive and they are TZM-white. The parental strain (1408) from which the two gerC-containing strains (1488 and 1558) were derived was also found to possess a TZM-white marker (Moir et al., 1979) and, later, to be defective in germination (R. J. Warburg, unpublished results). Crosses 8 to 11 (Table 2) demonstrate that a TZM-white marker near aroC7 is present in strains 9020 (7\% cotransformed), 1558 (10\% cotransformed) and 1408 ( $16 \%$ cotransformed) and thus may be near to the gerJ50 mutation (14\% cotransformed with aroC7, cross 7 ). None of the spore suspensions prepared from the recombinants were temperature-sensitive in L-alanine, but had similar germination (loss of absorbance and appearance under phase contrast) and resistance properties to those of strain 4750 (see below).

Thus, it would seem that we have not located the gerC58 and gerC 88 mutations but rather the TZM marker of strain 1408, and that this presumably spontaneous mutation is both genetically and physiologically similar to gerJ50. This marker can thus be referred to as gerJ51.

Before they could be used in the above crosses the markers aroC7 and $\operatorname{aroB2}$ had to be transduced by phage PBS1 into strains 1506 and 1604, respectively. This was necessary because the original strains carry TZM-white mutations which made it impossible to score for the presence of gerJ50 TZM marker. We have found that many laboratory strains have such markers, and in the case of the $\mathrm{Aro}^{-}$strains we have found that they form spores that are unable to germinate in L-alanine but will do so in a mixture of glucose, fructose, asparagine and $\mathrm{KCl}$. These properties are like those of strains with mutations in the GerA region (Moir et al., 1979), which are the most commonly isolated germination mutants in our laboratory. The locations of the markers on the chromosome are in at least two areas-those linked to lys-1 (gerJ51) and those unlinked to lys-1 (TZM markers from the Aro strains, as shown by 


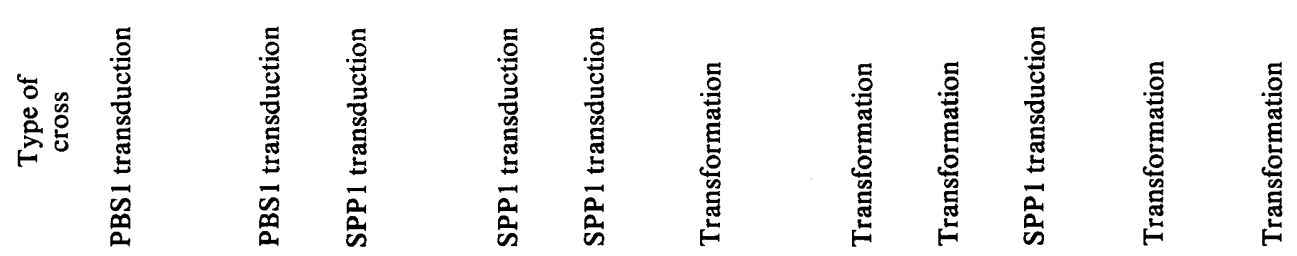

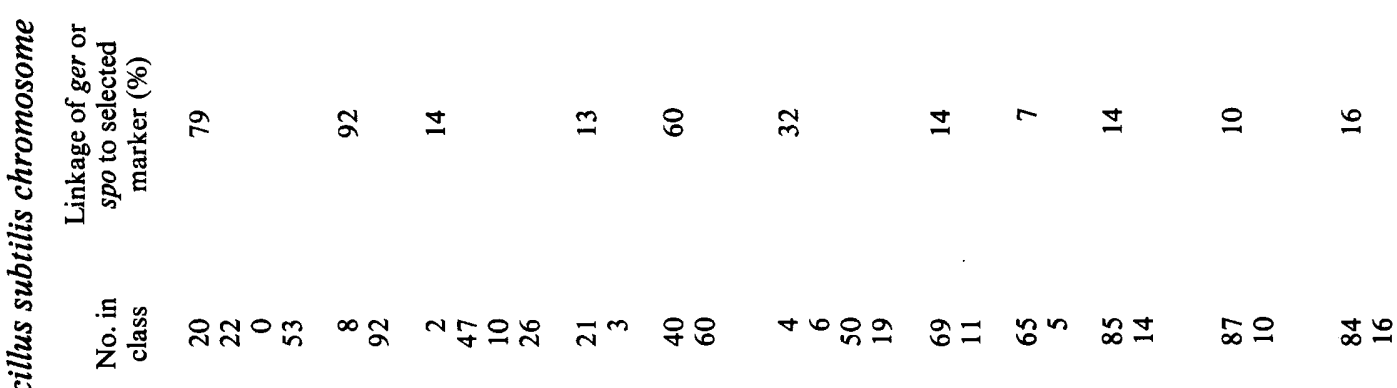

芯

ฐ

ธิธี



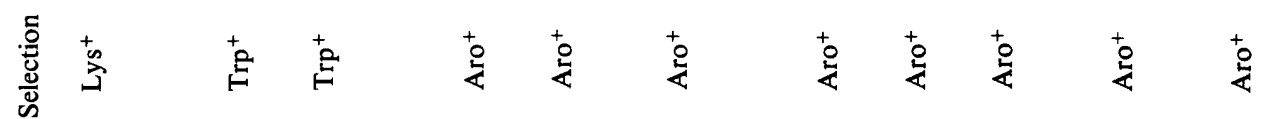

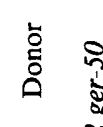
ปี⿻

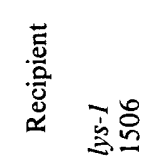
总

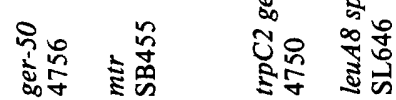

光
帘

की

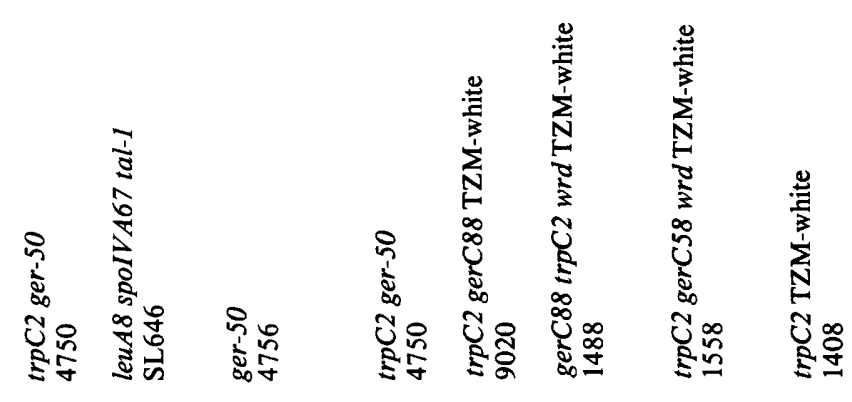

ถี कै

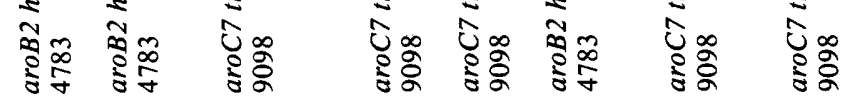



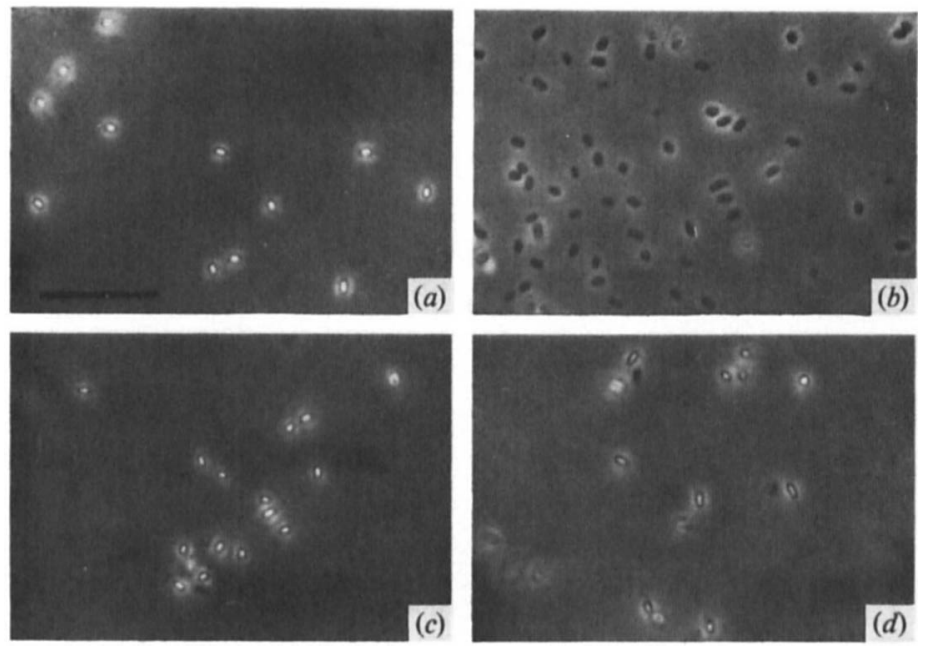

Fig. 1. Changes in spores during germination, as seen by phase contrast microscopy. Dormant spores of the wild-type, $1604(a)$ and mutant, $4750(c)$ and germinated spores (incubated in $1 \mathrm{mM}$-L-alanine for $30 \mathrm{~min}$ at $37^{\circ} \mathrm{C}$ ) of the wild-type $(b)$ and mutant $(d)$ were mounted in $0.5 \%$ agar and photographed through a Leitz phase contrast microscope. The bar marker represents $10 \mu \mathrm{m}$.

PBS1 crosses used to transduce the Aro markers into strain 1506 or 1604). The presence of such TZM markers in strains with differing origins may well reflect some selective pressures for germination deficiencies during the storage and recovery of laboratory stocks.

\section{Germination properties of mutant 4750 (gerJ50)}

For each property, experiments were carried out on at least three separately prepared suspensions of both mutant and wild-type spores.

Loss of absorbance. After $30 \mathrm{~min}$ in the presence of L-alanine, or a mixture of glucose, fructose, asparagine and $\mathrm{KCl}$, or $\mathrm{PAB}$, the wild-type spore suspension lost $60 \%$ of its absorbance and the spores became phase-dark, whereas spores of the mutant lost $35 \%$ of their absorbance and the majority reached only a phase-grey stage (Fig. 1, 2a). About $10 \%$ of the mutant spores did become phase-dark after $30 \mathrm{~min}$ and in PAB could outgrow and undergo vegetative cell division; those that reached only the phase-grey stage did not outgrow even after $6 \mathrm{~h}$ in PAB. The recovery from spores of colonies on NA, however, was normal.

Loss of dipicolinic acid and resistance. Spores of the wild-type and the mutant contained similar amounts of DPA [6.6 \pm 0.6 (s.D.) and $6.9 \pm 0.5 \%$ of dry weight, respectively] and they released their DPA during germination in $1 \mathrm{mM}$-L-alanine in an identical manner (Fig. $2 a$ ); the loss of resistance to heat, octanol, chloroform and toluene showed a similar pattern. Thus, although spores of the mutant only reached a phase-grey stage, their loss of DPA and changes in resistances were similar to those of wild-type spores.

Requirement of spores for germination in L-alanine. Spores of the wild-type are able to germinate in a buffered solution of L-alanine (Moir et al., 1979). As the concentration of L-alanine is increased the rate of germination (defined as the rate of loss of $A_{580}$ ) also increases up to a maximum. The concentration of $\mathrm{L}$-alanine at which the rate of germination is half that of the maximum value $\left(C_{50}\right)$ can thus be used as an estimate of the affinity of the spores for the germinant (Sammons et al., 1981). The $C_{50}$ value for the mutant $(3.5 \pm 0.7 \times$ $\left.10^{-5} \mathrm{M}\right)$ was not significantly different from that of the wild-type $\left(4.3 \pm 0.6 \times 10^{-5} \mathrm{M}\right)$.

Release of hexosamine-containing fragments. Wild-type spores release these fragments at a similar rate to their loss in absorbance during germination. This reaction was complete after $30 \mathrm{~min}$ with approximately $35 \%$ of the total spore hexosamine $(3 \cdot 3 \pm 0 \cdot 2 \%$ of dry weight) 

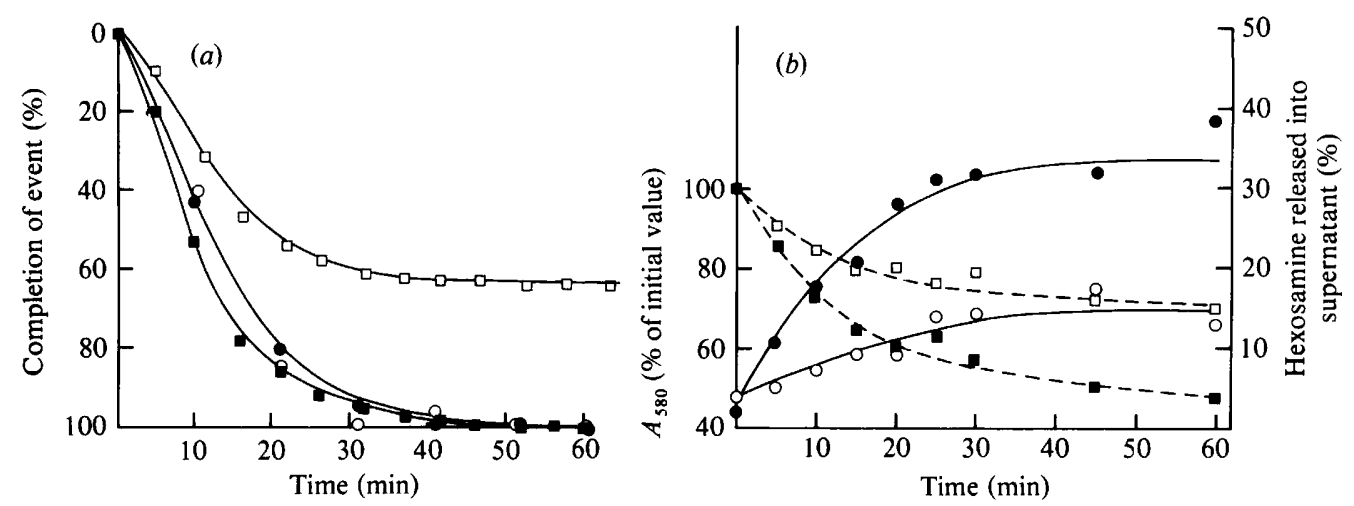

Fig. 2. Loss of absorbance $\left(A_{580}\right)$ and release of dipicolinic acid (DPA) and hexosamine-containing fragments during germination of spores in L-alanine. ( $a$ ) The fall in $A_{580}$ of a suspension of heat-activated spores in L-alanine was followed with time. At intervals $3 \mathrm{ml}$ samples were taken and, after filtering, the DPA content of the filtrate was measured. The loss of $A_{580}$ and release of DPA for wild-type spores at 60 min was taken as $100 \%$ completion of that event (at this time $60 \%$ of the initial $A_{580}$ had been lost and $100 \%$ of the initial DPA content had been released into the supernatant). Release of DPA: $O$, mutant (4750); $O$, wild-type (1604). Loss of $A_{580}: \square$, mutant; $\square$, wild-type.

(b) Heat-activated spores were suspended to an $A_{580}$ of 40 ; at intervals $1 \mathrm{ml}$ samples were taken and centrifuged for $2 \mathrm{~min}$ at $12000 \mathrm{~g}$. The hexosamine contents of both the pellets and supernatants were determined, and the $A_{580}$ of a 1 in 30 dilution of each sample was measured. Percentage of the total spore hexosamine released into the supernatant: $O$, mutant $(4750)$; $O$, wild-type (1604). $A_{580}: \square$, mutant; $\mathbf{0}$, wild-type.

having been released. Spores of the mutant also released such fragments but both the rate and the total amount released (15\%) were lower (Fig. $2 b$ ) although the total hexosamine content $(2.6 \pm 0.9 \%$ of dry weight) was similar to that of wild-type spores. The kinetics of release of hexosamine-containing material and of the fall in absorbance, as seen from the shapes of the curves in Fig. 2(b), were similar to those for wild-type spores. This would argue against a slower lytic response in the mutant since the loss of fragments from both the mutant and wild-type stops at the same time.

\section{Resistance levels of spores}

The viable counts of spore suspensions of the wild-type and mutant were both unaffected by octanol (recoveries were $100 \pm 28$ and $90 \pm 9 \%$ of the untreated control, respectively) while both were somewhat lower after toluene treatment $(64 \pm 18$ and $60 \pm 10 \%$, respectively). The chloroform resistance of both wild-type and mutant spores was low $(17 \pm 4$ and $38 \pm 6 \%$, respectively); this may reflect one effect of the sporulation medium on spore properties (normal resistance levels of 60-80\% were observed for both wild-type and mutant spores prepared by the resuspension method of Sterlini \& Mandelstam, 1969). Mutant spores were not sensitive to heating at $70^{\circ} \mathrm{C}$ for $30 \mathrm{~min}$, but unlike wild-type spores $(98 \pm 31 \%$ recovery) the number of colony-forming units increased after this heating procedure (198 \pm $20 \%$ ). This might reflect a requirement of some mutant spores for heat activation before germination can occur, which is not possessed by wild-type spores. However, there was no evidence of such an effect when spore suspensions that had been heated for 0-60 min at $70^{\circ} \mathrm{C}$ were germinated in L-alanine and the fall in absorbance was followed. Heating at $90{ }^{\circ} \mathrm{C}$ (Fig. 3) revealed that the mutant spores were considerably more sensitive than wildtype spores, with a $D_{90}$ of about 8 min compared with $40 \mathrm{~min}$ for the wild-type.

We found no evidence of any sensitivity to lysozyme $\left(200 \mu \mathrm{g} \mathrm{ml}^{-1}\right)$ even after $1 \mathrm{~h}$ at $37^{\circ} \mathrm{C}$ for both the wild-type and strain 4750 . Spore suspensions of the lysozyme-sensitive strain 4600 treated in a similar manner showed a sharp drop in $A_{580}$ and complete lysis of the spores. 


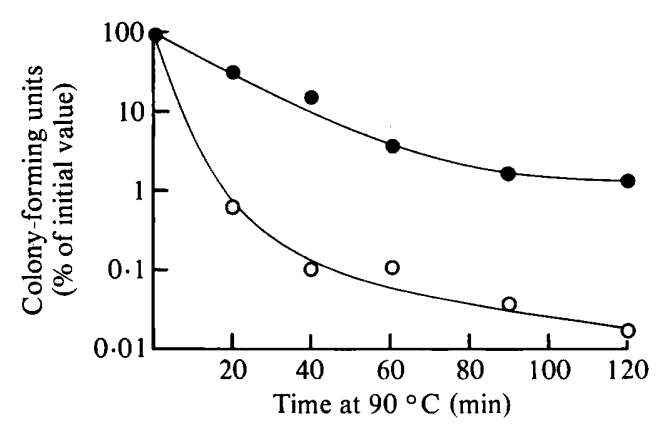

Fig. 3. Heat sensitivity of spores at $90^{\circ} \mathrm{C}$. The number of colony-forming units at each sampling time was expressed as a percentage of the colony-forming units at time $0 . D_{90}$ was calculated as the time taken for the number of colony-forming units to fall to $10 \%$ of the initial value. $O$, mutant $(4750)$;, wild-type (1604).

\section{Morphological studies}

No difference was detected between wild-type and mutant spores either in thin sections of $\mathrm{KMnO}_{4^{-}}$or glutaraldehyde/osmium tetroxide-fixed preparations or in the freeze-fracture profiles of spores (Fig. $4 a-g$ ). The volumes of coat, cortex and core were similar; the average number of coat layers was the same and the distance between surface striations observed in freeze-fracture preparations was equal. However, in sections of spores germinated in $1 \mathrm{mM}$-L-alanine for $30 \mathrm{~min}$ the cores of wild-type spores filled the cortical space whilst those of mutant spores had not swollen to such an extent (Fig. $4 c, d$ ), as has been observed for other phase-grey spores (Santo \& Doi, 1974). A few (4-5\%) spores in germinated preparations of the wild-type had a similar morphology to germinated spores of the mutant (Fig. 4e), showing that the wild-type spores passed through the morphological stage reached by the mutant spores. The observation that approximately $10 \%$ of the mutant spores do become phase-dark was paralleled by a similar number of the sectioned spores having fully swollen cores. It is interesting to note the difference between the freeze fractures of wild-type spores prepared on PGYEA (Fig. $4 f$ ) and those prepared in the resuspension medium of Sterlini \& Mandelstam (1969), the latter having a knobbled appearance compared with the smooth lines of the former (Fig. 4h). This feature was also seen in freeze fractures of mutant spores and represents an effect that the medium can have on spore structure (Waites et al., 1979).

\section{DISCUSSION}

We have isolated a spore germination mutant, 4750 , containing the mutation gerJ50 that is unlike those previously described (Moir et al., 1979). Spores of this mutant and of the wild-type both respond to all the germinants that have been tested; however, those of the mutant only reach a phase-grey stage, whilst wild-type spores pass through this stage and become phase-dark. This suggests that the trigger reaction (O'Connor \& Halvorson, 1959) in these spores is normal, and this is further supported by the similar L-alanine concentration required for germination. When germination was measured by following the loss of resistance properties, or the release of DPA, we found that the mutant spores had an identical phenotype to those of the wild-type, showing that they are not only triggered but also undergo the first few reactions of the germination process normally, These observations correspond well to those made by Hashimoto et al. $(1969 a, b)$ in their work on inhibitors and single spore germination in Bacillus cereus. They found that one phase, including the partial hydration of the core, the partial loss of absorbance and the release of DPA, took place in the presence of inhibitors, whilst the remaining reactions did not. Our mutant seems to carry out the processes involved in the first phase, but not in the later one. 

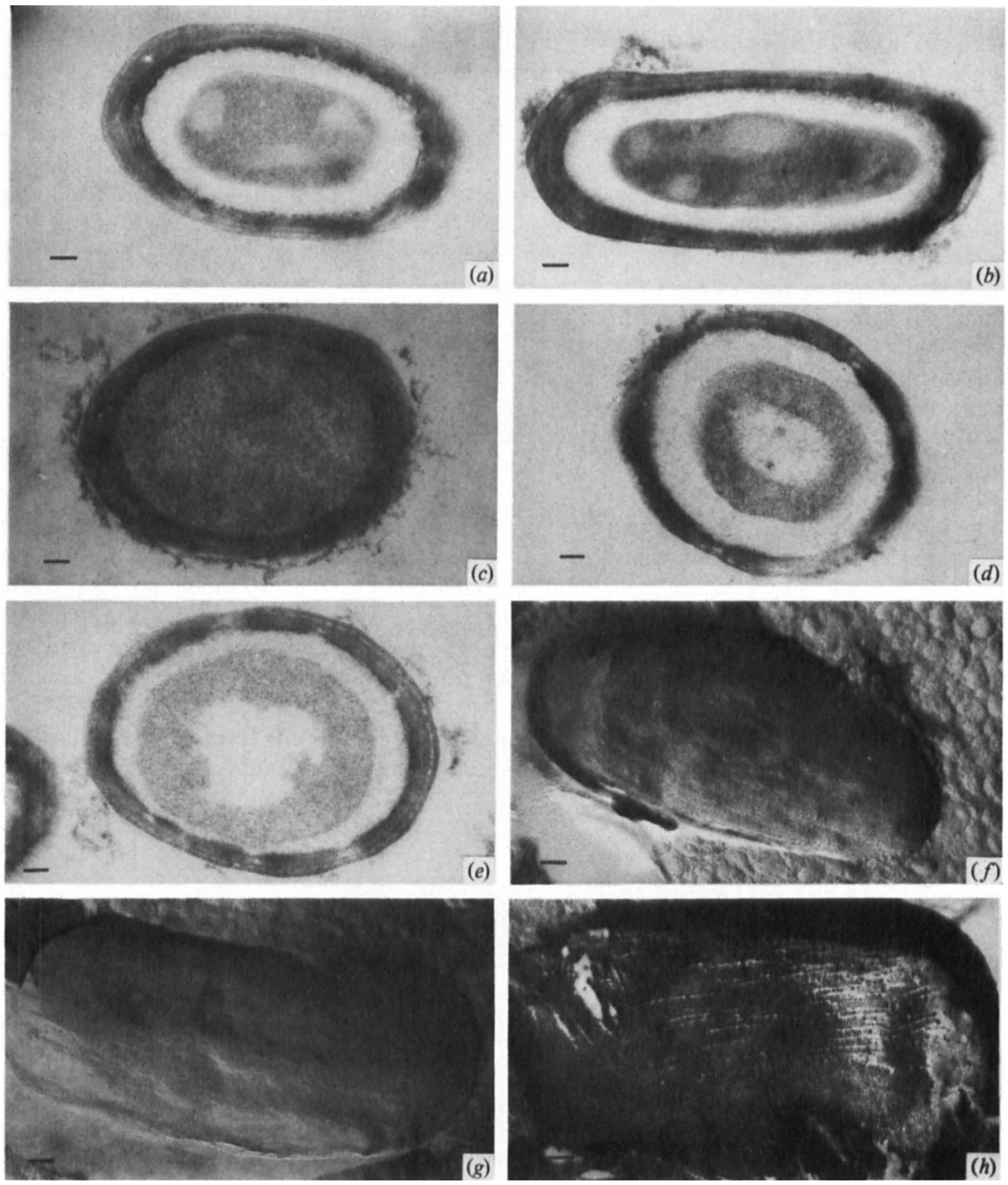

Fig. 4. Electron micrographs of dormant and germinated spores. Suspensions of dormant spores of the wild-type, $1604(a)$ and mutant, $4750(b)$ and of germinated spores ( $30 \mathrm{~min}$ at $37^{\circ} \mathrm{C}$ in $1 \mathrm{~mm}$-L-alanine) of the wild-type $(c, e)$ and mutant $(d)$ were fixed in $1 \% \mathrm{KMnO}_{4}$ before embedding and cutting sections. Freeze fractures were made at $-110^{\circ} \mathrm{C}$ on dormant spore suspensions of the wild-type $(f)$ and mutant $(g)$, and then coated with $\mathrm{Pt} / \mathrm{C}$. A freeze fracture was also made of a spore suspension of the wild-type $(h)$ prepared in the resuspension medium of Sterlini \& Mandelstam (1969) at $26^{\circ} \mathrm{C}$. The bar markers represent $0.1 \mu \mathrm{m}$.

Mutants of $B$. cereus with similar germination characteristics to mutant 4750 have been isolated (Aronson \& Fitz-James, 1975; Cheng \& Aronson, 1977; Cheng et al., 1978; Stelma et al., 1980), but all of these have been shown to be lysozyme-sensitive and/or to possess a defective spore coat. From the electron microscopy and the resistance properties this does not seem to be true for gerJ50 spores, but further studies, especially of the coat proteins, are 
needed. Some of the mutants of $B$. cereus also lack an intracellular protease activity (Cheng et al., 1978) and this is accompanied by both a coat and germination deficiency. Again, this is not so for strains containing gerJ50 for they have normal intracellular protease activities (R. J. Warburg, unpublished results). The germination mutant 4600 (containing gerE36) of $B$. subtilis (Moir, 1981) forms coat-defective spores but has a similar germination phenotype to strain 4750 as it reaches only a phase-grey stage. However, the map location of gerE36 is different ( $99 \%$ cotransduced with citF by phage PBS1). In addition, spores of strain 4600 do not lose all of their DPA and behave in a less synchronous manner; only $50 \%$ of the spores become phase-grey after $30 \mathrm{~min}$ in L-alanine compared with $95 \%$ for gerJ50. From this it may be concluded that strain 4600 is probably blocked at a different stage of germination than 4750 . GerE36 is clearly pleiotropic, and this could also be so for gerJ5O since the sensitivity of its spores to heating at $90^{\circ} \mathrm{C}$ may well be due to a structural defect unassociated with resistance to the chemicals tested or to heating at $70^{\circ} \mathrm{C}$ and undetectable by electron microscopy.

The slow and incomplete release of hexosamine-containing fragments during germination of the mutant spores may point to some form of a lytic enzyme deficiency. It may, on the other hand, indicate that fewer targets or sites in the spore peptidoglycan are susceptible to attack by a particular lytic enzyme, resulting in less release during germination. However, the hexosamine content of both wild-type and mutant spores is similar, and therefore any deficiency would have to be not in the total hexosamine but in its composition, probably in the structure or proportion of the cortical peptidoglycan. This would explain the observed heat $\left(90^{\circ} \mathrm{C}\right)$ sensitivity of the spores, because the cortical peptidoglycan may well be disrupted and so its function of keeping the core under pressure (Dring \& Gould, 1975) could be impaired.

Whatever the cause of the deficiency in spores of strain 4750 it is a very useful mutant for the study of germination since it permits division of the process into three stages, i.e. the trigger response, the subsequent events that take place in both the mutant and wild-type and those that occur only in the wild-type.

We are most grateful to Dr D. Hidy for the gift of $O$-carbamyl-D-serine and to all those who donated strains. We would like to thank Professor G. W. Gould and Mr G. J. Dring of Unilever Research Laboratories for their continuous interest and for their help with the electron microscopy. We are also indebted to Dr J. Finean and $\mathrm{Mr}$ D. Mills for their help in the use of the Department of Biochemistry's freeze-fracturing machine. For many useful discussions and the careful reading of the manuscript, we are grateful to Dr D. A. Smith and for help at the start of the project we are indebted to Dr R. L. Sammons and Miss J. Sudlow. Technical help was expertly provided by Mrs J. Yeomans, Mrs C. Davies and Mrs S. Haley. R. W. is supported by a research studentship from the Medical Research Council and A.M. is a Research Fellow of the Science Research Council.

\section{REFERENCES}

Anagnostopoulos, C. \& Spizizen, J. (1961). Requirements for transformation in Bacillus subtilis. Journal of Bacteriology 81, 741-746.

Aronson, A. I. \& Fitz-James, P. C. (1975). Properties of Bacillus cereus spore coat mutants. Journal of Bacteriology 123, 354-365.

Cheng, Y.-S. E. \& ARonson, A. I. (1977). Alterations of spore coat processing and protein turnover in a Bacillus cereus mutant with a defective postexponential intracellular protease. Proceedings of the National Academy of Sciences of the United States of America 74, 1254-1258.

Cheng, Y.-S. E., Fitz-James, P. \& Aronson, A. I. (1978). Characterisation of a Bacillus cereus protease mutant defective in an early stage of spore germination. Journal of Bacteriology 133, 336-344.
DrING, G. J. \& Gould, G. W. (1971). Sequence of events during rapid germination of spores of Bacillus cereus. Journal of General Microbiology 65, 101104.

DrING, G. J. \& Gould, G. W. (1975). Reimposition of heat resistance on germinated spores of Bacillus cereus by osmotic manipulation. Biochemical and Biophysical Research Communications 66, 202208.

Ferrari, E., Canosi, U., Galizzi, A. \& Mazza, G. (1978). Studies on transduction process by SPP 1 phage. Journal of General Virology 41, 563-572.

Gould, G. W. (1969). Germination. In The Bacterial Spore, pp. 397-444. Edited by G. W. Gould \& A. Hurst. London: Academic Press.

Hamilton, W. A. \& Stubbs, J. M. (1967). Com- 
parison of the germination and outgrowth of spores of Bacillus cereus and Bacillus polymyxa. Journal of General Microbiology 47, 121-129.

Hashimoto, T. \& GerhardT, P. (1960). Monochromatic ultraviolet microscopy of microorganisms - preliminary observations on bacterial spores. Journal of Biophysical and Biochemical Cytology 7, 195-196.

hashimoto, T., Frieben, W. R. \& Conti, S. F. $(1969 a)$. Germination of single bacterial spores. Journal of Bacteriology 98, 1011-1020.

Hashimoto, T., Frieben, W. R. \& Contl, S. F. $(1969 \mathrm{~b})$. Microgermination of Bacillus cereus spores. Journal of Bacteriology 100, 1385-1392.

Hoch, S. O., Roth, C. W., Crawford, I. P. \& Nester, E. W. (1971). Control of tryptophan biosynthesis by the methyltryptophan resistance gene in Bacillus subtilis. Journal of Bacteriology $105,38-45$.

LAFFerTy, E. \& MoIr, A. (1977). Further studies on conditional germination mutants of Bacillus subtilis 168. In Spore Research 1976, pp. 87-105. Edited by A. N. Barker, J. Wolf, D. J. Ellar, G. J. Dring \& G. W. Gould. London: Academic Press.

LuFT, J. H. (1956). Permanganate - a new fixative for electron microscopy. Journal of Biophysical and Biochemical Cytology 2, 799-802.

MARMUR, J. (1961). A procedure for the isolation of deoxyribonucleic acid from micro-organisms. Journal of Molecular Biology 3, 208-218.

Molr, A. (1981). Germination properties of a spore coat-defective mutant of Bacillus subtilis 168. Journal of Bacteriology (in the Press).

MoIr, A., LAfFERTY, E. \& SMiTh, D. A. (1979). Genetic analysis of spore germination mutants of Bacillus subtilis 168: the correlation of phenotype with map location. Journal of General Microbiology 111, 165-180.

Nester, E. W., Schafer, M. \& Lederberg, J. (1963). Gene linkage in DNA transfer; a cluster of genes concerned with aromatic biosynthesis in Bacillus subtilis. Genetics 48, 529-551.

O'ConNor, R. S. \& Halvorson, H. O. (1959). Intermediate metabolism of aerobic spores: alanine deamination during germination of spores of Bacillus cereus. Journal of Bacteriology 78, 844851.

Piggot, P. J. (1973). Mapping of asporogenous mutations of Bacillus subtilis: a minimum estimate of the number of sporulation operons. Journal of Bacteriology 114, 1241-1253.

Powell, J. F. \& StRange, R. E. (1953). Biochemical changes during the germination of bacterial spores. Biochemical Journal 54, 205-209.

Sammons, R. L., MoIR, A. \& SMith, D. A. (1981). Isolation and properties of spore germination $\mathrm{mu}$ - tants of Bacillus subtilis 168 deficient in the initiation of germination. Journal of General Microbiology 124, 229-241.

Santo, L. W. \& DoI, R. H. (1974). Ultrastructure analysis during germination and outgrowth of Bacillus subtilis spores. Journal of Bacteriology 120 , 475-481.

ScotT, I. R. \& Ellar, D. J. (1978). Study of calcium dipicolinate release during bacterial spore germination by using a new, sensitive assay for dipicolinate. Journal of Bacteriology 135, 133-137.

Scott, I. R., Stewart, G. S. A. B., Koncewicz, M. A., Ellar, D. J. \& Crafts-Lighty, A. (1978). Sequence of biochemical events during germination of Bacillus megaterium spores. In Spores VII, pp. 95-103. Edited by G. Chambliss \& J. C. Vary. Washington, D.C.: American Society for Microbiology.

Sousa, J. C. F., Silva, M. T. \& Balassa, G. (1974). Biochemical genetics of bacterial sporulation. V. Fine structure analysis of two sporulation mutants of Bacillus subtilis derepressed for late functions. Molecular and General Genetics 128, 261-272.

SPURR, A. R. (1969). A low viscosity epoxy resin embedding medium for electron microscopy. Journal of Ultrastructure Research 26, 31-43.

Stelma, G. N., JR, Aronson, A. I. \& Fitz-James, P. C. (1980). A Bacillus cereus mutant defective in spore coat deposition. Journal of General Microbiology 116, 173-185.

Sterlini, J. M. \& Mandelstam, J. (1969). Commitment to sporulation in Bacillus subtilis and its relationship to actinomycin-resistance. Biochemical Journal 113, 29-37.

Trowsdale, J. \& SMith, D. A. (1975). Isolation, characterisation and mapping of Bacillus subtilis 168 germination mutants. Journal of Bacteriology 123, 83-95.

VARY, J. C. \& Halvorson, H. O. (1965). Kinetics of germination of Bacillus spores. Journal of Bacterio$\operatorname{logy} 89,1340-1347$.

Waites, W. M., Stansfield, R. \& Bayliss, C. (1979). Effect of sporulation medium on the structure and heat resistance of spores of Clostridium bifermentans. FEMS Microbiology Letters 5, 365368 .

WARTH, A. D. (1971). Action of spore lytic enzymes on the cortex. In Spores $V$, pp. 28-34. Edited by H. O. Halvorson, R. Hanson \& L. L. Campbell. Washington, D.C.: American Society for Microbiology.

Wolf, J. \& MAHMoud, S. A. Z. (1957). The effects of $\mathrm{L}$-alanine and $\mathrm{D}$-alanine on the germination of some Bacillus spores. Journal of Applied Bacteriology $\mathbf{2 0}$, 373-383. 